Kinestetik : Jurnal Ilmiah Pendidikan Jasmani 5 (1) (2021)

Kinestetik : Jurnal Ilmiah Pendidikan Jasmani

https://ejournal.unib.ac.id/index.php/kinestetik/index

DOI : 10.33369/jk.v5i1.14358

\title{
CIRCUIT LEARNING MODEL BASED "AKIDAH" IN MODIFIED VOLLEYBALL FOR ELEMENTARY SCHOOL STUDENTS
}

\author{
Pungki Indarto ${ }^{1 *}$, Gatot Jariono ${ }^{2}$, Muhammad Faiz ${ }^{3}$, Rafli Muhammad ${ }^{4}$, Dwi Endri \\ Mei Minawati ${ }^{5}$ \\ ${ }^{12345}$ Sports Education, Teacher Training and Education, Universitas Muhammadiyah Surakarta
}

\section{Article Info}

Article History :

Received :February 2021

Revised : February 2021

Accepted :March 2021

Available online :March 2021

Keywords:

Akidah, Circuit learning, modified volleyball

\begin{abstract}
This development research resulted in a circuit learning model based on AKIDAH in modified volleyball games in elementary schools. This model is packaged in circuit form. The purpose of this research is to develop a learning model in accordance with the characteristics of elementary school students. The samples in this study were students of SD Muhammadiyah Special Program Baturan, Griyan Baturan Colomadu with a sample of research is grade 4 and 5 students numbering 40 people using pruposive sampling technique. The method used was the development research of Borg and Gall. The data collection instruments used were questionnarires, and mini volleyball game test instruments, while data analysis used qualitative and quantitative descriptions. The stages of this research are (1) needs analysis; (2) development; (3) small group trials; (4) The product effectiveness test uses the skills of playing modified volleyball with the results obtained using the skills of serving, passing, and smash. The results showed that the expert validation of the learning model was $75.5 \%$ very valid. $76.2 \%$ material expert analysis very valid categories. The test results are moderate in 35 categories. Overall the analysis of the 82.6 model with the category deserves a good predicate.
\end{abstract}

\begin{tabular}{llr}
\hline Corresponding address & : Windan Baru. Jl. Hamzah III. No. 26. RT & ISSN 2685-6514 (Online) \\
& 04/RW 07 Gumpang, Kartasura, & ISSN 2477-331X (Print) \\
& Sukoharjo, Jawa Tengah & \\
*Corresponding email & $:$ pi311@ @ums.ac.id
\end{tabular}




\section{INTRODUCTION}

Physical education has the meaning of achievement of competencies and objectives contained in the curriculum at the education unit level (Department for Education, 2013). Teachers have a role to play in organizing the learning process. Seeing how successful learning should be able to bring a dynamic learning atmosphere, paying attention to the interaction of educators and learners,takess a learning atmosphere that remain interesting (Mansyur, 2020).

Physical education becomes one of the containers to maintain the quality of a person's physical condition. (Jariono \& Subekti, 2020) and (Indarto et al., 2018) revealed that motivation and interest in sports activities. Games are fun one of them with circuit learning.(Pratama \& Hudah, 2020) and (Hartanti et al., 2020). learning is learning through a gamebased learning approach (Maulidina et al., 2018) by dividing the shape of circuits in several posts from easy and without tools to difficult with tools to solve problems in AKIDAH-based circuit learning activities

Emphasis in religious learning through analysis, creative, innovative, demontrative, active, and humanist. Having the intention in the implementation of physical Education learning based on curriculum 2013 must be able to develop the participation rate of learners to be active, teachers provide innovative analysis and models, as well as forms of evaluation in accordance with child development (humanist) (Fikri \& Hardiyono, 2020). This is (Light \& Harvey, 2017) line game-based circuit learning involving analysis, games, dialogue, and reflection processes can be projected on the form of sports learning and the future.

The modification volleyball learning model developed must be following the needs of students in elementary school children which includes methods communication patterns (Ianda \& Richi, 2020) and (Sukari et al., 2020). Circuit learning with the AKIDAH approach is necessary to include learning components that are Analytical, Creative, Innovative, Demonstrative, Active, and Humanist.

The battery-based circuit model inmodifyied volleyball games was developed to instill the value of character manifested in the form of moralityy (Bariah \& Assya'bani, 2019) stated that morality is an ingrained trait in a person's soul due to the sudden appearance of deeds (Subahri, 2015); (Subahri, 2015)(Subahri, 2015); (Subahri, 2015) (Subahri, 2015). The role of education in instilling morall values must be taught from an early age by optimizing the role of teachers and establishing effective communication the practical level. Both statements above can be interpreted that a proper game learning model is needed using a humanist approach to pay attention to the growth and development of learners (Jumarudin et al., 2014).

Physical Education, Sports, and Health aims to form a whole human being that covers the realm of affective, cognitive, psychomotor by prioritizing social values as a form of character implementation (Mustafa \& Dwiyogo, 2020). Looking at this phenomenon and the description of the problem above, it is necessary to play an important role in the learning of Physical Education Sports, and Health. Researchers are trying to develop a akidah-based circuit learning model on modified volleyball for elementary school children.

\section{METHODS}

This research usesthe developmentt method (Sugiyono, 2016) with steps adapted from borg and gall. There are 4 necessary stages, namely, (1) preliminary 
research; (2) development planning; (3) validation, evaluation, and revision; and (4) implementation of the model.

\section{Participants}

This research was carried out at SD Muhammadiyah Special Program Baturan, Griyan Baturan Colomadu with a sample of research is grade 4 and 5 students numbering 40 people. The sampling technique uses purposive sampling because the sample taken is to consider the age characteristics of elementary school students to develop one of the games in the sport, namely volleyball through a research and development approach.

\section{Sampling Procedures}

This sampling procedure i purposive sampling. This research requires consideration on the grounds of the characteristics of learners. The criteria in purposive sampling are taking into account the age and class taught in the volleyball game, namely grades 4 and 5. Because in these classes the motor skills of children are already in the development stage and can be taught in volleyball games.

\section{Materials and Apparatus}

Data collection techniques are carried out in three activities: (1) Literature Studies to determine the nature and scope in the developed system; (2) Researching faith-based circuit learning in modified volleyball games for elementary schools; (3) Questionnaires are used to collect data on the type of faith-based circuit learning inmodifyied volleyball games against elementary school students.

The results of data collected from library studies, research, and field surveys were analyzed using quantitative descriptive. The objectives produced in the form of prototype models include the basis of theory, problem identification, identification of objectives, device materials, implementation mechanisms, trials, and final products. The data obtained is analyzed with the gain score formula and then matched in table 1 to see the aspects of its effectiveness.

Table 1. Feasibility level of AKIDAH-based circuit learning model

\begin{tabular}{lcc}
\hline No & Interval & Criteria \\
\hline 1 & $86 \%-100 \%$ & Very feasible \\
\hline 2 & $76 \%-85 \%$ & Worth \\
\hline 3 & $60 \%-75 \%$ & Quite decent \\
\hline 4 & $55 \%-59 \%$ & Less worthy \\
\hline 5 & $\leq 54$ & Not worth it \\
\hline
\end{tabular}

In table 2, the assessment of the validators of learning models, material experts, teacher responses, and learners is presented.

Table 2. Validation assessment criteria, teacher and student response.

\begin{tabular}{lcl}
\hline No & Interval & \multicolumn{1}{c}{ Criteria } \\
\hline 1 & $76 \%-100 \%$ & Very Valid \\
\hline 2 & $51 \%-75 \%$ & Valid Enough \\
\hline 3 & $26 \%-50 \%$ & Invalid \\
\hline
\end{tabular}

\section{Procedures}

The procedure in this study consisted of three stages, namely (1) the first stage the researcher categorized the data to support and those that were not supported by the focus of this study. Then the researcher examined the relationship between the data and the results of field observations in order to obtain information during the study; (2) the second stage of the research pays attention to the data obtained, either in the form of direct statements or indirect conclusions related to the problem of this research; and (3) find the validity of the 
data through data triangulation. Triangulation of data in this study in the last step of data analysis is a technique of checking the validity of the data as a comparison of the interview data

\section{Design or Data Analysis}

The data analysis used in this study is a percentage descriptive analysis. Data analysis uses two techniques, namely qualitative analysis, and quantitative analysiss. the qualitativ analysis aims to describe the characteristics of the development of the medium-based volleyball model for quantitative analysis to illustrate how much feasibility the model is developed by using descriptive percentage analysis. For descriptive analysis of frequencies using Microsoft excel 2019.

\section{RESULT}

In the research and development of AKIDAH-based circuit learning modell, it can be described Descriptiv analysis of data aimed to describe the results of validation of learning experts, volleyball learning materials, teacher response, and student response. For more details can be described as follows:

\section{Learning Model Validation}

Table 4. Expert Validation of AKIDAHBased Circuit Learning Model

\begin{tabular}{clcc}
\hline No & \multicolumn{1}{c}{$\begin{array}{c}\text { Assessed } \\
\text { aspects }\end{array}$} & $\begin{array}{c}\text { Percentage } \\
(\%)\end{array}$ & $\begin{array}{c}\text { Criteri } \\
\text { a }\end{array}$ \\
\hline 1 & $\begin{array}{l}\text { Learning model } \\
\text { design }\end{array}$ & 74.3 & $\begin{array}{c}\text { Valid } \\
\text { Enough }\end{array}$ \\
\hline 2 & $\begin{array}{l}\text { Objectives of } \\
\text { the learning } \\
\text { model }\end{array}$ & 74.8 & $\begin{array}{c}\text { Valid } \\
\text { Enough }\end{array}$ \\
\hline 3 & $\begin{array}{l}\text { Learning model } \\
\text { activities }\end{array}$ & 75.2 & $\begin{array}{c}\text { Very } \\
\text { Valid }\end{array}$ \\
\hline
\end{tabular}

\begin{tabular}{cccc}
\hline 4 & $\begin{array}{c}\text { The benefits of } \\
\text { learning models }\end{array}$ & 77.6 & $\begin{array}{c}\text { Very } \\
\text { Valid }\end{array}$ \\
\hline $\begin{array}{c}\text { Average } \\
\text { results }\end{array}$ & $\mathbf{7 5 . 5}$ & $\begin{array}{c}\text { Very } \\
\text { Valid }\end{array}$ \\
\hline
\end{tabular}

Based on the result validation expert learning model about the design, objectives, activities, and benefits of the learning mode obtained resultss of $75.5 \%$. Based on these results, the results of the analysis of aspects of the AKIDAH-based circuit learning model are included in the criteria are very valid..

2. Validation of learning materials

Table 5. Modified volleyball Learning Expert Validation

\begin{tabular}{clcc}
\hline No & \multicolumn{1}{c}{$\begin{array}{c}\text { Assessed } \\
\text { aspects }\end{array}$} & $\begin{array}{c}\text { Percentage } \\
(\mathbf{\%})\end{array}$ & Criteria \\
\hline 1 l & $\begin{array}{l}\text { Content } \\
\text { coverage } \\
\text { learning } \\
\text { implementation } \\
\text { plan (RPP) }\end{array}$ & 76.1 & $\begin{array}{c}\text { Very } \\
\text { Valid }\end{array}$ \\
\hline 2 & $\begin{array}{l}\text { RPP } \\
\text { conformity } \\
\text { with } \\
\text { competence }\end{array}$ & 75.2 & Very \\
\hline 3 & $\begin{array}{l}\text { Learning } \\
\text { facilities and } \\
\text { media }\end{array}$ & 76.2 & Valid \\
\hline 4 & $\begin{array}{l}\text { Learning } \\
\text { methods }\end{array}$ & 78.7 & Very \\
\hline 5 & $\begin{array}{l}\text { Evaluation of } \\
\text { learning }\end{array}$ & 74.9 & Valid \\
\hline & $\begin{array}{l}\text { Average } \\
\text { results }\end{array}$ & $\mathbf{7 6 . 2}$ & $\begin{array}{c}\text { Valid } \\
\text { Valid }\end{array}$ \\
\hline & & & \\
\hline
\end{tabular}

The validation results of expert learning materials consisting of several indicators aching the contentt of the learning implementation plan (RPP), RPP conformity with competence, facilities and learning media, method learning, and evaluation of learning with competency obtained results of $76.2 \%$. Based on these results, the modifyied volleyball learning 
materials developed with an akidah-based circuit model obtained very valid criteria.

3. Teacher response of AKIDAH-based circuit learning model

Teacher response physical education, sports and health to faith-based circuit learning in the category of good. For more details can be seen in the following histogram:

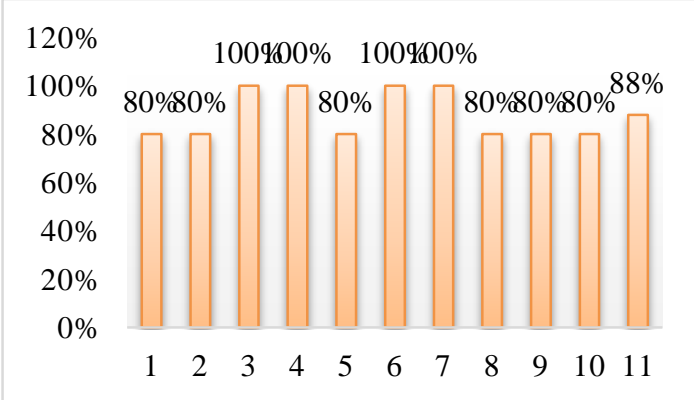

Figure 1. Histogram teacher response

At the time of the trial of the learning model, questionnaires were given to teachers consisting of: (i) Akidah-based circuit learning model suitable for modified volleyball games in elementary school,(ii) Akidah-based circuit learning model isfollowing expected competenciess, (iii) Stages of learning models are following learning activities teaching Physical Education Sports and Health,(iv) There are components of Analysis, Creative, Innovative, Demonstrative, Active, and Humanist (AKIDAH) in learning, (v) The model of akidah-based circuit learning is easy to implement, (vi) The implementation of learning is already student-centered,(vii) The learning model can give rise to social attitudes, (viii) The learning model placesteachers as facilitatorss, (ix) The implementation of the model is carried out effectively and efficiently, and (x) the learning model has maximized media andtechnology. Toget responses from akidah-based circuit learning models in modified volleyball games. The teacher's response questionnaire statement also provides input on the use of learning models. Teacher response results obtained a score of $88 \%$ with very valid criteria.

\section{Learner response to AKIDAH-based circuit learning model}

Learners' responses to faith-based circuit learning are in good categories. For more details can be seen in the following histogram:

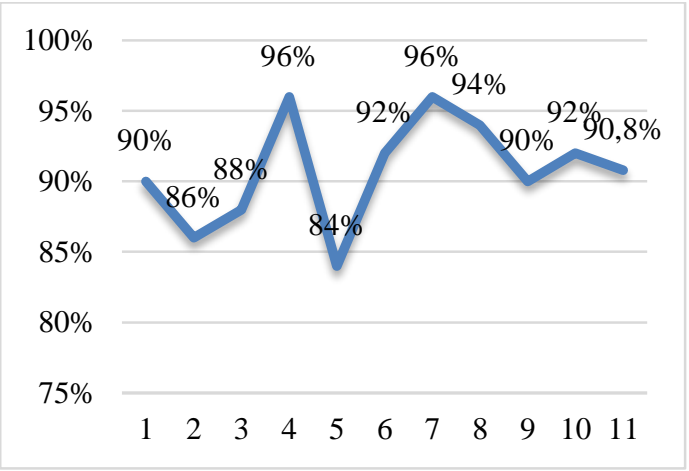

Figure 2. learner response graph

The students' response to the AKIDAH-based circuit learning model was given after the test. The results of the questionnaire obtained the suitability of the akidah-based circuit learning model to be applied to volleyball game materials in elementary school. AKIDAH-based circuit learning consists of: (i) AKIDAHbased circuit learning model suitable for modified volleyball games,(ii) AKIDAH-based circuit learning model trains critical thinking (curiosity,(iii) AKIDAH-based circuit learning model makes me easy to understand PJOK material,(iv) The AKIDAH-based Circuit Learning Modelis interestingand fun, (v) The model used makes creative and innovativee, (vi) The model used makes me want to move and play (Active and Demonstrative),(vii) The model can train social interaction (Cooperation. Care, help); (viii) The model used can foster confidence, honesty, and 
responsibility,(ix) The model used is easy todo, and (x) the model used uses safe and easy-to-operate media As for the results obtained by $90.8 \%$ or in the category of excellent for use in the learning of modified volleyball for elementary school students.

\section{Analysis feasibility of AKIDAH-based circuit learning model}

The feasibility analysis of the goal model is to find out which faith-based circuit learning for modified volleyball games is feasible or unfit for use in elementary school students. More details can be seen in the following table:

Table 6. Learning Model Feasibility Analysis

\begin{tabular}{lc}
\hline \multicolumn{1}{c}{ Aspects } & Percentage (\%) \\
\hline Model Validation & 75.5 \\
\hline Material Validation & 76.2 \\
\hline $\begin{array}{l}\text { Teacher Response } \\
\text { Questionnaire }\end{array}$ & 88 \\
$\begin{array}{l}\text { Student Response } \\
\text { Questionnaire }\end{array}$ & 90.8 \\
\hline Average & 82.6 \\
\hline
\end{tabular}

Based on table 6 to find out the feasibility of the model developed obtained from the overall analysis of both expert validation and the response questionnaire of teachers and learners. All data is summed and searched on average and then adjusted to the model feasibility criteria (Wulandari, 2017). From the results of the feasibility analysis of the learning model obtained $82.6 \%$ with a category worthy of a good predicate.

\section{DISCUSSION}

Gain score testing to obtain learning results. The gain score analysis was done using data on average pretest 40.3 and posttest average 61.5. Data obtained from the test results are then processed and carried out again score tes obtained a result of $35 \%$ with a moderate category. Validation of learning model obtained $75.5 \%$ result with a very valid category. The aspect that gets the highest score is the benefit of the learning model with $77.6 \%$. Aspects of benefits severall indicators arise including achievement of competence, fostering curiosity, fostering creativity, innovative, trying, and active.

This learning model is specifically developed in the motion activities of learners in the form of games that explore analytical thinking, creative, innovatione, demonstrativee, active, and humanist (AKIDAH). This goal is in line with the indicators of improving the quality of learning (Saifulloh et al., 2012) which states that the implementation of Education has several factors that it delivers are active participation of learners, creativity, innovation, providing examples, and instilling human values (Aminuddin Mohamed, 2019), Also, accordin to thatt the quality of the learning model was formed by teachers by presenting a conducive and enjoyable learning environment.

Validation of learning materials obtains a percentage of $76.2 \%$ with a very valid category. The aspect that has the highest value is the learning method with a percentage of $78.7 \%$ categorical is very valid. The method is prepared in the design of the implementation of learning by applying circuit learning consisting of 3 posts with 3 circuit on each post. Post 1. black-green, playing, fishnet; Post 2. play shoot antelope, play grab me, and bowling; and Post 3. practice serve, passing andd smash wit play approachh.

The teacher's response questionnaire was given during the trial of the akidah-based circuit learning model in modifyied volleyball game. 
The result obtained $88 \%$ with the category is very very valid and very appropriate. Aspects that get the highest score are the suitability of methods, social attitudes, components akidah, learning-centered on learners. All four aspects get a perfect score of 5 .

Observation of the implementation of learning models was carried out during the trial. The learning stage consists of (1) opening; (2) organizing; (3) mentoring and mentoring, (4) providing discussion and feedback,; (5) strengthening and evaluation. The results of observation of the implementation of the learning model is carried out $100 \%$, so that all stages can be carried out properly.

Questionnaires were given to learners of the AKIDAH-based circuit learning model in modified volleyball games by $90.8 \%$. The results of the questionnaire provide information that the highest aspects in table 9 are number 4 and 7, namely abou theoriess and formation of social values (cooperation, care, and mutual trust). (Surahni, 2017) explains that physical education, sports, and health develop human beings completely and uphold moral values in theory and practice. Another important aspect is humanists. (Jumarudin et al., 2014) that the need to instill religious character values as a form of mutual respect between educators and learners.

The result of model revision by paying attention to the rationality of the revised aspect, namely (1) revision of the number of circuits. On this rationality it is necessary to do because it sees the effectiveness and efficiency of time in learning; (2) changes to the content of the post. This was done in consideration of the Library's study of the burden of training in skill mastery to be gradual, ranging from simple to complex; (3) utilization of media. Pay attention to the purpose of learning abou modifyied volleyball games, so that the approach uses ball media; (4) learning environment. It is necessary to organize the learning environment to prepare a good quality of learning; (5) provide a direc experiencee (practice) of volleyball service, passing, and smash skills; (6) discussion and interaction space. Giving time for children to have social interactions; (7) equitable assistance. Teachers move during the learning process to assist with the obstacles experienced by the students.

The result of analysis of the test class gains score obtained a percentag off $35 \%$. This result is sufficient when matched with a predetermined category. However, this result is considered good considering the short trial time, which is 4 meetings. Ideally in a study learning takes a long time to obtain a change that is significant. Besides, the results of the study (Gustiawati, 2017); (Anif et al., 2019) that teachers are agents of change in guiding and helping students from th originally did not know to know.

Student learning results research was conducted for 4 months in 1 semester. (Hanief et al., 2018) found an increase in student practice learning outcomes after two cycles lasting two months. From the results of this study can be concluded that to obtain the results of learning that significant takes a relatively long time and required adaptation and intensive training.

Observing from the findings of previous research, the researcher can distinguish previous research, namely the research carried out is to find one of the learning models, namely how students and teachers can show analysis, creativity, innovation, demonstration, active, and humanist in the teaching and learning process. So that the learning process can be easily carried out by students, one of which is in learning volleyball games that are following the 
child's development and development abilities.

\section{CONCLUSION}

Research conducted at the stage of drafting a circuit-based learning model begins with an analysis of the needs of learners, then designing learning models, conducting validation and revisions to obtain a valid, interesting, and useful model with a percentage of $82.6 \%$ feasible with a good predicate, so that overall there is an increase in learner learning outcomes before and after the implementation of the faith-based circuit learning model in modified volleyball games. results obtained before treatment of 40.3 and after-treatment value of 61.5 with an effectiveness rate of $35 \%$

\section{REFERENCES}

Aminuddin Mohamed. (2019). Creativity and Inovation As an Indigenous Pedagogy. Journal of Educational Research and Indigenous Studies Volume:

Anif, S., Sutama, S., Prayitno, H. J., \& Sukartono, S. (2019). Kompetensi Profesional Guru Sekolah Menengah Pertama Kabupaten Kendal. Jurnal VARIDIKA.

https://doi.org/10.23917/varidika.v1i1.8 906

Bariah, K., \& Assya'bani, R. (2019). Integrasi Nilai Karakter dalam Pembelajaran Akidah Akhlak: Studi Pembelajaran Akidah Akhlak di MI Integral AlUkhuwwah Banjang. Al Qalam: Jurnal Ilmiah Keagamaan Dan Kemasyarakatan, 3(2), 139. https://doi.org/10.35931/aq.v3i2.169

Department for Education. (2013). Physical education programmes of study: key stages 3 and 4 National curriculum in England Purpose of study. London: DfE.

Fikri, A., \& Hardiyono, B. (2020). The Level Of Teachers Understanding In Physical Education, Sports And Health About The 2013 Curriculum. Kinestetik:
Jurnal Ilmiah Pendidikan Jasmani. https://doi.org/10.33369/jk.v4i2.12500

Gustiawati, R. R. (2017). Implementasi Model-Model Pembelajaran Penjas dalam Meningkatkan Kemampuan Guru Memilih dan Mengembangkan Strategi Pembelajaran Pendidikan Jasmani Olahraga dan Kesehatan. JOSSAE: Journal of Sport Science and Education. https://doi.org/10.26740/jossae.v1n1.p2 7-31

Hanief, Y. N., Subekti, T. B. A., \& Mashuri, H. (2018). Meningkatkan Hasil Belajar Passing Bawah Bolavoli melalui Permainan 3 on 3 pada Siswa Sekolah Dasar. JURNAL PENDIDIKAN JASMANI DAN OLAHRAGA. https://doi.org/10.17509/jpjo.v3i2.1241 4

Hartanti, M. D., Nurhasan, N., \& Syam Tuasikal, A. R. (2020). Pengaruh Pembelajaran Sirkuit Berbasis Pendekatan Saintifik Terhadap Hasil Belajar Dribble Dan Shooting Bola Basket. Multilateral Jurnal Pendidikan Jasmani Dan Olahraga. https://doi.org/10.20527/multilateral.v1 9i2.8614

Ianda, S., \& Richi, A. P. (2020). The Effect Of Commando Methods And Circuits Of Play On Basic Movement Skills Of Mini Bolavoli Game Sutra. Jurnal Guru Peneliti Professional.

Indarto, P., Subekti, N., \& Sudarmanto, E. (2018). Pengukuran Tingkat Minat dengan Bakat Mahasiswa Pendidikan Olahraga Universitas Muhammadiyah Surakarta. JSES : Journal of Sport and Exercise Science. https://doi.org/10.26740/jses.v1n2.p5761

Jariono, G., \& Subekti, N. (2020). Sports Motivation Survey And Physical Activity Students Of Sport Education Teacher Training And Education Faculty FKIP Muhammadiyah University Surakarta. Kinestetik : Jurnal Ilmiah Pendidikan Jasmani. https://doi.org/10.33369/jk.v4i2.12449

Jumarudin, J., Gafur, A., \& Suardiman, S. P. (2014). Pengembangan Model Pembelajaran Humanis Religius Dalam Pendidikan Karakter Di Sekolah Dasar. 
Jurnal Pembangunan Pendidikan: Fondasi Dan Aplikasi. https://doi.org/10.21831/jppfa.v2i2.262 3

Light, R. L., \& Harvey, S. (2017). Positive Pedagogy for sport coaching. Sport, Education and Society. https://doi.org/10.1080/13573322.2015. 1015977

Mansyur, A. R. (2020). Dampak COVID-19 Terhadap Dinamika Pembelajaran Di Indonesia. Education and Learning Journal. https://doi.org/10.33096/eljour.v1i2.55

Maulidina, M., Susilaningsih, S., \& Abidin, Z. (2018). Pengembangan Game Based Learning Berbasis Pendekatan Saintifik Pada Siswa Kelas Iv Sekolah Dasar. JINOTEP (Jurnal Inovasi Dan Teknologi Pembelajaran) Kajian Dan Riset Dalam Teknologi Pembelajaran. https://doi.org/10.17977/um031v4i2201 $8 \mathrm{p} 113$

Mustafa, P. S., \& Dwiyogo, W. D. (2020). Kurikulum Pendidikan Jasmani, Olahraga, dan Kesehatan di Indonesia Abad 21. JARTIKA Jurnal Riset Teknologi Dan Inovasi Pendidikan. https://doi.org/10.36765/jartika.v3i2.26 8

Pratama, N. Y., \& Hudah, M. (2020). Pendekatan Permainan Outbound Sirkuit Game Dalam Meningkatkan Kematangan Emosional Dan Spitual Melalui Pembelajaran Penjas Pada Siswa Smp N 1 Sumowono. Journal of Sport Coaching and Physical Education. https://doi.org/10.15294/jscpe.v5i1.365 66

Saifulloh, M., Muhibbin, Z., \& Hermanto, H. (2012). Strategi Peningkatan Mutu Pendidikan Di Sekolah. Jurnal Sosial Humaniora. https://doi.org/10.12962/j24433527.v5i 2.619

Subahri, S. (2015). Aktualisasi Akhlak Dalam Pendidikan. Islamuna: Jurnal Studi Islam, 2(2), 167. https://doi.org/10.19105/islamuna.v2i2. 660

Sugiyono. (2016). Metode Penelitian dan Pengembangan (Research and Development/R\&D). Bandung:
Alfabeta.

Sukari, S., Adji, T. P., \& Putro, K. H. (2020). Upaya meningkatkan servis atas bolavoli mini menggunakan metode pembelajaran game terhadap siswa sekolah dasar. Journal Of Sport Education (JOPE). https://doi.org/10.31258/jope.3.1.53-62

Surahni. (2017). Pendidikan Jasmani, Olahraga dan Kesehatan (PJOK) sebagai Sarana Pendidikan Moral. The 6th University Research Colloquium 2017.

Wulandari, Y. (2017). Kelayakan Aspek Materi Dan Media Dalam Pengembangan Buku Ajar Sastra Lama. Gramatika STKIP PGRI Sumatera Barat.

https://doi.org/10.22202/jg.2017.v3i2.2 049 